\title{
Effect entrepreneurship on innovation behavior and institutional environment: based on a comparative analysis
}

\author{
Xiaodi JIANG ${ }^{1 *}$ (D), Liping FU²
}

\begin{abstract}
To establish a basic model to evaluate the effect of entrepreneurship upon the organizational innovation, applying transaction costs and intellectual property right protection as institutional moderating variables. By collecting data from GEM's investigation, the dynamic connection between the entrepreneurship and innovation decision was explored and the differences in terms of innovation's motivations were statistically compared between the North and emerging countries. The entrepreneurship exerted positive effect on entrepreneurs' innovation decision. The decrease of transaction costs had positive moderating effect. With subsequent comparative analysis, the transaction costs exerted larger moderating effect, whereas intellectual property right protection had negative moderating effect in emerging countries. Individualized policy implications should be proposed according to the specific situations in emerging countries, which include adapting regional incubator, building information communication platform as well as applying appropriate intellectual property right protection.
\end{abstract}

Keywords: entrepreneurship; organizational innovation; intellectual property right protection; transaction cost.

Practical Application: Suggestions on how to active the organizational innovation in the background of emerging countries.

\section{Introduction}

Alone with the shifting of innovation personnel from science center and university to small-medium enterprises, technical innovation research is also under the transition from the analysis of static data to in-depth evaluation of motivationdecision mechanism. Consequently, entrepreneurship receives increasingly more interests from scholars as a vital motivation of innovation decision (Martin, 2016). Entrepreneurship has multiple dimensions which can affect the regional innovation, and the main mechanisms include knowledge creation, regional collaboration and technology commercialization (Stam, 2015; Wong et al., 2005; Delgado et al., 2010). However, due to the limitations of new-classical economics in analyzing decisionmaking and organizational behaviors, the effect of entrepreneurship on organizational innovation decision is like a "black box" to be expressed accurately (Teece, 2007). With the emerging theory of evolutionary economics and the classical paradigm of revolution, knowledge creation and organization heterogeneity, institutional environment of innovation seem to be the novel approaches to express the enterprise's innovation strategy in a specific area or life cycle (Boschma, 2005; Cantwell et al., 2010). As a vital part of regional innovation environment, whether the institutional environment can moderate the relationship between entrepreneurship and innovation behavior when it is perceived by entrepreneur remains elusive, which contributes to the adaptation of regional innovation environment and promotion of organizational open innovation in practical manners.
With rapid economic growth, the emerging countries, especially BRICS, have presented high start-up rate and self-employment rate, indicating a relative high static entrepreneurship. In spite of the high start-up rate, the ability of open and exploitative innovation in emerging countries still is still worse compared to that of the North. Therefore, the gap of innovation induces the shortage of competitive advantages, which becomes the main barrier in the process of catch-up. Considering the differences in terms of industry life cycle, social value and political issue, does the entrepreneurship and institutional environment play the same roles in different countries? Should the emerging countries shape the similar institutional environment to promote the focal companies' motivation of innovation? These questions are of significance to the scholars and policy makers in developing countries. To explore the environmental issues which would act as the moderating force in the relationship between entrepreneurship and innovation decision, scholars in the evolutionary economics seek to explain the difference regarding the organizational learning, imitation and innovation behavior between countries in different backgrounds through the mechanism of institutional environment's path creation (Misra et al., 2014; Ghazinoory et al., 2017).

In this investigation, based on the differences between North and emerging countries, transaction costs and intellectual property right protection were utilized as the institutional environment variables and the moderating effect of institutional factors on the relationship between entrepreneurship and organizational 
innovation was evaluated. Besides, the ideologies of "enterprise heterogeneity" and innovation motivation with a dynamic scope were applied in both the model and variable design. According to analyzing the relationship between institutional environment and inner motivation, policy implications were put forward for emerging countries to transform focal enterprises from high start-up rate to high organizational innovation efficiency.

\section{Literature review}

\subsection{Entrepreneurship and innovation}

Entrepreneurship originates from the motivation of a participant to all the affairs concerning about business. Schumpeter constructed different entrepreneurship dimensions and linked them with organizational innovation, he stated that entrepreneurship could positively affect the innovation and compared innovation as butter and bread which gained from risky and diligent entrepreneurs (Schumpeter, 1934). Alone with the shifting of multiple-participant innovation, enterprise plays a vital role in the innovation because the deep perception and easy access to market could make up the drawback of university and policy maker. Consequently, how and through which mechanism entrepreneurship could affect the innovation become a hot topic in the field of technical innovation. In the perspective of regional innovation, Stuetzer et al. (2016) and Carree et al. (2002) have applied start-up and self-employment rate to measure entrepreneurship and demonstrated that entrepreneurship could positively affect the efficiency of regional innovation, which is defined as static entrepreneurship (Hébert \& Link, 2006). Nevertheless, static entrepreneurship also receives criticism due to the following drawbacks. Firstly, static entrepreneurship is a regional indicator failing to reflect the heterogeneity of enterprises. Secondly, static entrepreneurship could not differentiate survival start-up and innovative entrepreneurship (Noseleit, 2013). Dynamic entrepreneurship could adapt the drawbacks of static entrepreneurship. Scholars have summarized the dimensions of dynamic entrepreneurship mainly including adventure preference, professional knowledge and willingness to open up new business (Schumpeter, 1928; Teece et al., 1997). Audretsch applies those dynamic indicators in his empirical study of US Small Business Innovation Research, whereas the research turns out that dynamic entrepreneurship drives small- and medium-sized enterprises to participate in the national innovation project and improves the innovation ability of organizations (Audretsch et al., 2016). Subsequently, Acs has proposed that the dynamic entrepreneurship is positively associated with the tendency of organizational innovation (Acs \& Audrestch, 1988). Zhao has indicated that opportunity start-up is vital motivation to the innovation behavior of decision makers (Zhao, 2005). To unlock the "black box" between entrepreneurship and organizational innovation, the authors propose following hypothesis based on previous findings:

- H1. Dynamic entrepreneurship (adventure preference, knowledge and experience, willingness of start-up) would promote the organizational innovation.

\subsection{The moderating effect of transaction costs on entrepreneurship and innovation}

Transaction costs is a classic theory in the institutional economics constructed by Coase which indicates the cost in making any economic trade when participating in a market (Coase, 1960). Transaction costs can also be explained as the costs for bounded rational decision-maker to search information, which is also regarded as a reflection of regional institutional environment (Williamson, 1989). The effect of transaction costs on innovation is a classical and widely-discussed topic. Gooroochurn \& Hanley (2007) have proven that the decline of transaction costs can promote the innovation in the aspect of specialization of R\&D. Grossman \& Hart (1986), Hart \& Moore (1990) have utilized the theory concerning about investment specialization to express why low transaction costs can boost the innovation efficiency. In the scope of organization, the costs of information searching exert more significant effect on innovation decision including innovation pattern (in-house or outbound) and innovation efficiency compared with bargaining and contract costs (Love \& Roper, 2002). Evaluating the relationship between innovation and information searching cost has become the mainstream in the field of transaction costs. Scholars in developed countries tend to recognize the invert- $\mathrm{U}$ relationship between information searching cost and organizational innovation (Ferreras-Méndez et al., 2016). When the information searching cost is regarded as a moderating factor between entrepreneurship and innovation behavior, the influence is likely to become more complicated. Lundvall has suggested that the lower information searching cost perceived by entrepreneurs can promote both the knowledge capture and free-rider tendency (Lundvall, 1993), which are definitely contrary in terms of influencing organizational open innovation. Moreover, researchers have applied transaction costs as moderating variable and mostly focused on the acquisition and application of knowledge (Heiman et al., 2004). How transaction costs moderate the relationship between entrepreneurship and organizational innovation remains largely unknown. To deepen the understanding of this issues, the authors propose the following hypothesis:

- H2. The lower transaction costs can positively moderate the relationship between entrepreneurship and organizational innovation.

\subsection{The moderating effect of intellectual property right protection on entrepreneurship and innovation}

Intellectual property right is a pivotal institution in human social civilization because it can control the "possessive effect" of knowledge. The connection between innovation and intellectual property right protection has been widely explored. According to Helpman (1993), the protection of intellectual property right can turn technically-advanced companies into monopolies and lower the motivation of open innovation of other companies. Helpman also suggests that intellectual property right protection can disturb outbound innovation through the reduction of knowledge spillover. In terms of international trade, following Lai, high intellectual property right protection can offer more market opportunities to the leading firms in North and promote 
their innovation efficiency (Lai, 1998). Intellectual property right protection is a double-edge sword because it would both reduce the opportunity of organizational outbound innovation and boost inbound innovation and collaborative innovation (Popa et al., 2017). In recent years, due to the direct connection between intellectual property right protection and innovation, more and more explorers tend to accept the invert- $\mathrm{U}$ relationship and the centrality of research turns to find the optimal protection threshold for countries in different backgrounds (Park, 2008). On the ground of evolutionary economics, intellectual property right is one of the environmental factors which would also moderate the effect of other factors on the organizational or regional innovation. Several studies have proven that the moderating effect is positive and innovation devotion is one of the independent variables (Shinkle \& Kriauciunas, 2012). However, the entrepreneurship as the issue moderated by intellectual property right has been rarely studied. Therefore, the authors put forward the following hypothesis:

- H3. Intellectual property right protection can positively moderate the relationship between entrepreneurship and organizational innovation.

\subsection{Institutional environment in emerging and developed countries}

Due to the different development stages and technical distance, organizations in different backgrounds may have different responses to transaction costs between emerging countries and North. For instance, enterprises in developing countries seek low transaction costs to absorb more knowledge to shorten the life cycle of innovation and rise the position on global value chain (Gooris \& Peeters, 2016), whereas organizations in developed countries are mostly embedded in the high position or dominate the value chain, they usually have low elasticity to the knowledge spillover as well as transaction costs in the process of organizational innovation. Some leading firms even emigrate their lab out of the industry agglomeration area in oversea market (Grigorios \& Lamin, 2015). Consequently, the moderating effect of transaction costs is supposed to be higher in emerging countries. Intellectual property right protection is an institutional environment which exist a deep gap between emerging and developed countries. Whether the developing countries should follow the degree of protection in developed countriesis a controversial topic. With the review of existing literatures, Laplume et al. (2014) argues that the difference of democracy, openness and social value are the primary factors determining effectiveness of intellectual property right protection. Above all, intellectual property right protection is supposed to have larger restriction and effectiveness in developed countries (Aparicio et al., 2016). Based on the literature review of institutional environment, the authors propose the following hypotheses:

- H4. Transaction costs exert more significant moderating effect the relationship between entrepreneurship and organizational innovation between emerging countries and North.

- H5. Intellectual property right protection exert more significant moderating effect the relationship between entrepreneurship and organizational innovation between emerging countries and North (Table 1).
Table 1. Taxonomy of transaction costs and intellectual property rights in innovation.

\begin{tabular}{|c|c|c|}
\hline Study and method & Main ideas & Predictions \\
\hline \multicolumn{3}{|l|}{ Transaction costs } \\
\hline $\begin{array}{l}\text { Gooroochurn \& Hanley } \\
\text { (2007), empirical study } \\
\text { (UK) }\end{array}$ & $\begin{array}{l}\text { Capital and R\&D } \\
\text { density (direct) }\end{array}$ & Absorptive ability \\
\hline $\begin{array}{l}\text { Martin }(2002) \text { Model } \\
\text { reduction }\end{array}$ & $\begin{array}{c}\text { Knowledge } \\
\text { spillover (indirect) }\end{array}$ & $\begin{array}{c}\text { Spillover negatively } \\
\text { moderates innovation } \\
\text { and profits }\end{array}$ \\
\hline $\begin{array}{l}\text { Ferreras-Méndez et al. } \\
\text { (2016), empirical study } \\
\text { (Europe) }\end{array}$ & $\begin{array}{l}\text { Information } \\
\text { searching costs }\end{array}$ & $\begin{array}{c}\text { Reduction of } \\
\text { information } \\
\text { searching costs has } \\
\text { "invert-U" influence } \\
\text { on organizational } \\
\text { innovation }\end{array}$ \\
\hline $\begin{array}{l}\text { Heiman et al. (2004), } \\
\text { Framework construction }\end{array}$ & $\begin{array}{c}\text { Knowledge } \\
\text { acquire and utilize }\end{array}$ & $\begin{array}{l}\text { Connection between } \\
\text { knowledge acquire and } \\
\text { innovation is positive } \\
\text { moderated by TC }\end{array}$ \\
\hline \multicolumn{3}{|l|}{$\begin{array}{l}\text { Intellectual property } \\
\text { right protection }\end{array}$} \\
\hline $\begin{array}{l}\text { Cohen et al. (2000), } \\
\text { empirical study (US) }\end{array}$ & $\begin{array}{l}\text { Technology } \\
\text { exclusive } \\
\text { (moderator) }\end{array}$ & $\begin{array}{l}\text { IPR promote } \\
\text { innovation through } \\
\text { extend technology's } \\
\text { leading period }\end{array}$ \\
\hline $\begin{array}{l}\text { Martin }(2002), \text { Model } \\
\text { reduction }\end{array}$ & $\begin{array}{l}\text { Knowledge } \\
\text { specialization } \\
\quad \text { (direct) }\end{array}$ & $\begin{array}{l}\text { Knowledge } \\
\text { specialization promote } \\
\text { innovation }\end{array}$ \\
\hline $\begin{array}{l}\text { Wang (2011), empirical } \\
\text { study (China) }\end{array}$ & $\begin{array}{l}\text { IPR and regional } \\
\text { innovation (direct) }\end{array}$ & $\begin{array}{l}\text { IPR promote the } \\
\text { innovation while the } \\
\text { effect is marginal effect } \\
\text { is decrease }\end{array}$ \\
\hline $\begin{array}{l}\text { Wu \& Tang (2016), } \\
\text { empirical study (China) }\end{array}$ & $\begin{array}{l}\text { IPR and } \\
\text { organizational } \\
\text { innovation (direct) }\end{array}$ & $\begin{array}{l}\text { IPR positively affect } \\
\text { companies' innovation } \\
\text { efficiency and } \\
\text { performance }\end{array}$ \\
\hline
\end{tabular}

\section{Methods}

\subsection{Study method and sample collection}

The mainly-applied databases are Adult Population Survey (APS) and National Expert Survey (NES) in Global Entrepreneurship Monitor (GEM). GEM is an effective project which holds in-depth interview in different countries and offers various categories of data to scholars. Between two databases, APS focuses on measuring individual's potential and performance of entrepreneurship whereas NES concentrates on finding local experts' perception of entrepreneurship and environmental issues in specific regions. With regard of measuring intellectual property right protection and control variables, the databases of World Bank, OECD as well as Property Right Alliance were also applied. To make a comparison between emerging countries and developed countries in terms of institutional environment's effect, the BRICS (Brazil, Russia, India, China, South-Africa) and five typical OECD countries (US, UK, Canada, German, Australia) were selected as the research targets. The time period is the new edition of the database (2014). In consideration of calculating the 
innovation outcome, the authors eliminated the samples which did not represent the position of decision makers. After the process of data filtering, a total of 793 valid samples were obtained. With regard of the dependent variable was discontinuous, multiple logistics regression models were also adopted.

\subsection{Variable and data design}

To test the previous hypotheses, the basic model was given as Equation 1:

$O I_{i}=\alpha+\beta$ Xent $i+\theta X c I+e_{i}$

where $\mathrm{OI}$ is the organizational innovation, $\beta, \theta$ and e are vectors of entrepreneurship, control variable and the idiosyncratic error term.

The independent variable was entrepreneurship. In previous researches, many indicators were applied which normally included static entrepreneurship (Stuetzer et al., 2014) and dynamic entrepreneurship (Liu et al., 2017). With the regard the dynamic entrepreneurship could differentiate the survival start-up and opportunity entrepreneurship, dynamic entrepreneurship was chosen as an independent variable. Because of the dynamic entrepreneurship has several dimensions, three different variables were utilized to measure the entrepreneurship. The first variable was the preference of adventure and the measurement of the variable was the degree of decision-makers' fear of risk in the process of decision-making (Qi8). Second variable was the professional knowledge and the entrepreneurs' knowledge and experience were applied in the specific industry (Qi7). The last variable was opportunity entrepreneurship which was measured by the degree of willingness to start-up of decision-makers that have been interviewed (Q1A1).

In terms of measuring the organizational innovation, various approaches were adopted. Conventionally, scholars apply patent, new product sales (profit) as well as new product listed on magazine (Bettencourt et al., 2007; Pellegrino et al., 2012). Because of the heterogeneity of organizations, the size, location and industry sector exert effect on traditional innovation outcome. Consequently, the variable concerning about decision-makers' perception of the innovativeness and commercialization of the product were selected in this investigation, which was related to the question about new product's feedback from customers (Q1G1). The results of this question (Equation 2) reflected three degrees of organizational innovation.

$O I_{i}=\alpha+\beta$ Xent $i$ Xins $i+\theta X c I+e_{i}$

where $\mathrm{X}^{\text {ins }}$ is the institutional environment which includes information searching costs and intellectual property right protection.

The authors decided to identify suitable benchmarking variables to measure these two moderating variables. Transaction costs is normally measured by the degree of difficulty of information searching in a certain region (Lee \& Han, 2016). In the database of NES, experts in different countries have the difficulty of access of knowledge and technology (E02). Five scales are available to measure the cost of information searching and the mean value of all the experts in one country was calculated as the final transaction costs. Intellectual property right protection is determined by the legislation level, enforcement level as well as the citizen's awareness (Zhan, 2013). The International Property Right index held by Property Right Alliance has an authorized rating the degree of property right protection in each country. Among all the indicators in this report, the degree of intellectual property right protection was an indicator which integrated protection intellectual property, patent and copyright. In this study, the degree of intellectual protection was utilized as a variable of institutional environment.

Economic development can reflect the industry structure, industry life cycle and quality of labor capital in a certain region, which affect the organizational innovation (Lee et al., 2016). In this research, economic development was controlled and measured by gross national production per person and the number was taken logarithm. The technical incubating environment is directly related to the innovation behavior. The expert's marking of incubators instead of the number of regional incubators is applied to evaluate regional explorative ability (Mas-Verdú et al., 2015). Moreover, the degree of acceptance of innovation in a region (IO4) is marked by the expert and the data are from NES. In the organizational level, according to Schumpeter, firm size can affect the organizational innovation (Schumpeter II). To control the influence of firm size, the number of the stuff of the interviewed entrepreneurs is utilized to measure firm size (Jansen et al., 2005; Veugelers, 1997). Education indicates a decision-maker's training and his vision, which affect the organizational capability. In this research, the entrepreneurs' educational degree was adopted to measure their education level. All variables are illustrated in Table 2.

Table 2. Variable design and measurement.

\begin{tabular}{|c|c|c|c|}
\hline Variable & Abbreviation & Variable description & $\begin{array}{c}\text { Data } \\
\text { Source }\end{array}$ \\
\hline $\begin{array}{l}\text { Organizational } \\
\text { innovation }\end{array}$ & OI & $\begin{array}{c}\text { Dummy variable of } \\
\text { innovation }\end{array}$ & $\begin{array}{l}\text { APS: } \\
\text { Q1G1 }\end{array}$ \\
\hline $\begin{array}{l}\text { Adventure } \\
\text { preference }\end{array}$ & $\mathrm{AD}$ & $\begin{array}{c}\text { Attitudes towards risk } \\
\text { handling }\end{array}$ & $\begin{array}{l}\text { APS: } \\
\text { Qi4 }\end{array}$ \\
\hline $\begin{array}{l}\text { Knowledge and } \\
\text { experience }\end{array}$ & $\mathrm{KE}$ & $\begin{array}{l}\text { Previous experience } \\
\text { and knowledge }\end{array}$ & $\begin{array}{l}\text { APS: } \\
\text { Qi3 }\end{array}$ \\
\hline Willing to start-up & SP & $\begin{array}{l}\text { Attitudes towards } \\
\text { start-up }\end{array}$ & $\begin{array}{l}\text { APS: } \\
\text { Q1A2 }\end{array}$ \\
\hline Transaction cost & TC & $\begin{array}{c}\text { Benchmark of } \\
\text { information-search }\end{array}$ & $\begin{array}{l}\text { NES: } \\
\text { E02 }\end{array}$ \\
\hline $\begin{array}{l}\text { Intellectual } \\
\text { property right }\end{array}$ & IPR & $\begin{array}{l}\text { Grade of IPR } \\
\text { protection }\end{array}$ & IPRI \\
\hline $\begin{array}{c}\text { Economic } \\
\text { development }\end{array}$ & EG & GNI per person & $\begin{array}{l}\text { World } \\
\text { Bank }\end{array}$ \\
\hline Innovation culture & IC & $\begin{array}{c}\text { Benchmark of } \\
\text { innovation culture }\end{array}$ & NES: I04 \\
\hline $\begin{array}{l}\text { Incubating } \\
\text { environment }\end{array}$ & Inc & $\begin{array}{c}\text { Benchmark of regional } \\
\text { incubator }\end{array}$ & $\begin{array}{l}\text { NES: } \\
\text { C02 }\end{array}$ \\
\hline Firm size & Sca & Number of stuff & $\begin{array}{l}\text { APS: } \\
\text { Q1H1 }\end{array}$ \\
\hline Education & Edu & Educational degree & $\begin{array}{l}\text { APS: } \\
\text { DUC }\end{array}$ \\
\hline
\end{tabular}




\subsection{Descriptive analysis}

The descriptive analysis of variables was demonstrated in Table 3. The data were separated into two parts according to the "BRICS" and OECD countries. In the three dimensions of entrepreneurship, entrepreneurs in the emerging countries had a higher start-up tendency, consistent with high start-up rate in developing countries. Besides, the adventure-preference and skills of decision-makers in OECD countries were better than those in emerging countries, suggesting that decision-makers in emerging countries had relatively less status-quo preference while decision-makers in developed countries had better perception and vision of the situation. Regardless of the type of innovation, enterprises in emerging countries supplied more new products and services to the market. The institutional environment between two groups yielded the largest gap compared to the other variables. The transaction costs and intellectual property right protection in emerging countries were significantly lower than those in OECD countries. These two variables indicated the distance of informal institutional environment. The regional control variables reflected the distance between two groups in economic development, attitude towards innovation as well as organization incubating environment. The firms in OECD countries were larger in size and the entrepreneurs had higher educational degree.

\section{Results and discussion}

To test the relationship between entrepreneurship and organizational innovation, multiple logistics regression models were established and the low innovation level was regarded as the control group in this investigation. Consequently, medium and high organizational innovation is demonstrated in each model. As illustrated in Table 4, the first two models merely included control variables, whereas in the model 3 and model 4 , the educational degree positively affected the organizational innovation but the effect was not significant. The firm size did not affect the innovation decision. Economic development significantly negatively affected the organizational innovation, inconsistent with previous findings. It should be noted that the entrepreneurs in emerging and OECD countries are facing different industry

Table 3. Descriptive analysis of different variables between BRICS and OECD countries.

\begin{tabular}{ccccccccc}
\hline & \multicolumn{4}{c}{ The "BRICS" (499) } & \multicolumn{5}{c}{ The OECD Countries (294) } \\
\hline & Min & Max & Mean & Std & Min & Max & Mean & Std \\
OI & 1 & 3 & 1.83 & 0.70 & 1 & 3 & 1.67 & 0.78 \\
AP & 0 & 1 & 0.27 & 0.45 & 0 & 1 & 0.18 & 0.38 \\
SU & 0 & 1 & 0.48 & 0.5 & 0 & 1 & 0.37 & .482 \\
KE & 0 & 1 & 0.77 & 0.42 & 0 & 1 & 0.92 & 0.27 \\
IPR & 4.1 & 7.8 & 5.65 & 0.77 & 7.4 & 8.4 & 7.78 & 0.32 \\
TC & 1.65 & 2.96 & 2.17 & 0.32 & 2.08 & 2.58 & 2.41 & 0.14 \\
IC & 2.4 & 3.35 & 2.75 & 0.22 & 2.79 & 3.59 & 3.28 & 0.27 \\
ED & 7.35 & 9.51 & 8.94 & 0.42 & 10.69 & 11.08 & 10.88 & 0.11 \\
Inc & 2.69 & 3.64 & 3.42 & 0.32 & 3.15 & 3.98 & 3.56 & 0.24 \\
Sca & 0 & 80 & 4.08 & 7.51 & 0 & 15000 & 131.88 & 1279.33 \\
Edu & 0 & 4 & 1.94 & 0.89 & 0 & 4 & 2.62 & 0.14 \\
\hline
\end{tabular}

Max is the maximum value, Min is the minimum value, Mean is the mean value, Std is standard deviation.
Table 4. Effect of entrepreneurship on organizational innovation.

\begin{tabular}{|c|c|c|c|c|}
\hline & Model 1 & Model 2 & Model 3 & Model 4 \\
\hline & Medium OI & High OI & Medium OI & High OI \\
\hline Low KE & & & 0 & 0 \\
\hline High KE & & & -0.46 & -0.09 \\
\hline Low AP & & & 0 & 0 \\
\hline High AP & & & $0.71^{\star *}$ & 0.37 \\
\hline Low SU & & & 0 & 0 \\
\hline High SU & & & 0.12 & $0.57^{\star}$ \\
\hline EG & $-0.78^{\star *}$ & $-1.25^{\star *}$ & $-0.84^{* *}$ & $-0.77^{\star *}$ \\
\hline Inc & $1.16^{* *}$ & $0.79^{\star *}$ & $1.17^{\star *}$ & $0.66^{*}$ \\
\hline IC & $0.66^{* *}$ & $1.66^{* *}$ & $0.77^{\star}$ & $1.67^{* *}$ \\
\hline Sca & -0.01 & -0.02 & -0.01 & -0.01 \\
\hline Edu & 0.14 & 0.69 & 0.16 & 0.1 \\
\hline Cox\&Snell R² & 0.103 & 0.103 & 0.126 & 0.126 \\
\hline Negelkerke $\mathrm{R}^{2}$ & 0.118 & 0.118 & 0.144 & 0.144 \\
\hline
\end{tabular}

${ }^{* *} \mathrm{p}<0.01 ;{ }^{*} \mathrm{p}<0.05$.

life cycles. Emerging countries have more industries in the initial part of life cycle and the changeable environment. Therefore, the decision-makers should make more changes in the product and supply chain. The incubating environment exerted positive effect on the organizational innovation because the information platform, venture capital and suggestion offered by incubators assisted the entrepreneurs to create new product and service. Lastly, the social value towards innovation also promoted the organizational innovation because many countries are attempting to suit the innovative national culture (Godart et al., 2015).

Model 3 and model 4 added three variables of entrepreneurship, model 3 reflected the medium organizational innovation and model 4 indicated high innovation tendency. The knowledge and experience of decision-makers exerted no positive effect on innovation. However, the adventure-preference exerted significantly positive effect upon the organizational innovation, indicating that the pioneering spirit of entrepreneurship can make the decision-makers more confident to cope with the problems during the decision-making process of innovation. The last variable, start-up tendency positively affected organizational innovation, especially in the group of high organizational innovation effectiveness. Most dimensions of entrepreneurship could promote the organizational innovation, which validated the hypothesis 1 .

To assess the moderating effect of institutional environment (hypotheses 2 and 3), interactive variables of institutional environment (transaction costs and intellectual property right protection) and entrepreneurship were supplemented into the logistics regression models. After the process of centralization of dummy variables, the outcomes are shown in Table 5. In spite of the control variables and three dimensions of entrepreneurships tested in last section, transaction costs exerted significant moderating effect. In correspondence with the hypothesis, transaction costs exerted negative moderating effect on the relationship between the start-up, adventure-preference and 
Table 5. Moderating effect of institutional environment.

\begin{tabular}{|c|c|c|c|c|c|c|}
\hline & $\begin{array}{l}\text { Medium } \\
\text { OI }\end{array}$ & $\begin{array}{c}\text { High } \\
\text { OI }\end{array}$ & $\begin{array}{l}\text { Medium } \\
\text { OI }\end{array}$ & $\begin{array}{c}\text { High } \\
\text { OI }\end{array}$ & $\begin{array}{l}\text { Medium } \\
\text { OI }\end{array}$ & $\begin{array}{c}\text { High } \\
\text { OI }\end{array}$ \\
\hline $\mathrm{KE}$ & 0.05 & -4.68 & & & & \\
\hline $\mathrm{KE}^{\star} \mathrm{TC}$ & 1.32 & 2.01 & & & & \\
\hline $\mathrm{KE}^{\star} \mathrm{IPR}$ & $-0.48^{\star}$ & 0.05 & & & & \\
\hline $\mathrm{AP}$ & & & $4.96^{*}$ & $5.93^{*}$ & & \\
\hline $\mathrm{AP}^{\star} \mathrm{TC}$ & & & $-2.56^{\star *}$ & $-3.55^{* *}$ & & \\
\hline $\mathrm{AP}^{\star} \mathrm{IPR}$ & & & 0.01 & 0.29 & & \\
\hline SU & & & & & $5.39^{* *}$ & $6.59^{* *}$ \\
\hline $\mathrm{SU}^{*} \mathrm{TC}$ & & & & & $-1.88^{\star *}$ & $-1.62^{*}$ \\
\hline $\mathrm{SU}^{\star} \mathrm{IPR}$ & & & & & -0.16 & $-0.37^{\star}$ \\
\hline EG & $-0.79^{\star *}$ & $-0.81^{\star *}$ & $-0.97^{* *}$ & $-0.98^{* *}$ & $-0.71^{\star *}$ & $-0.65^{\star *}$ \\
\hline Inc & $1.15^{* *}$ & $0.79^{*}$ & $1.04^{* *}$ & $0.75^{\star}$ & $1.06^{* *}$ & 0.50 \\
\hline IC & $0.73^{*}$ & $1.67^{\star *}$ & $0.91^{\star}$ & $2.07^{\star *}$ & 0.32 & $1.31^{\star \star}$ \\
\hline Sca & -0.01 & -0.01 & -0.01 & -0.01 & -0.01 & -0.01 \\
\hline Edu & 0.13 & 0.05 & 0.17 & 0.08 & 0.1 & 0.05 \\
\hline Cox\&Snell R ${ }^{2}$ & 0.113 & 0.113 & 0.14 & 0.14 & 0.128 & 0.128 \\
\hline Negelkerke $\mathrm{R}^{2}$ & 0.129 & 0.129 & 0.16 & 0.16 & 0.146 & 0.146 \\
\hline
\end{tabular}

${ }^{* *} \mathrm{p}<0.01 ;{ }^{*} \mathrm{p}<0.05$

organizational, suggesting that the lower information-searching cost offers risky and pioneering decision-makers more access to knowledge and collaborator to promote organizational innovation. The relationship between entrepreneurial skills and organizational innovation was positively moderated by the transaction costs. Lowering information searching cost would decrease knowledgeable and experienced entrepreneurs' tendency of innovation decision-making, which confirmed the hypothesis 2 .

In hypothesis 3 , the intellectual property right protection exerted positive but not significant moderating effect on the relationship between adventure-taken and organizational innovation. The other two categories of entrepreneurship's influence of organizational innovation were negatively moderated by intellectual property right protection, especially the willingness to start-up, which rejected the hypothesis 3 , indicating that the "proper effect" brought by the intellectual high property right protection could not motivate all the enterprises in different developing stages to seek organizational innovation. Before discussing the policy suggestions, it was necessary to compare the effect of institutional environment in different countries (hypotheses 4 and 5).

According to the hypotheses 4 and 5 , transaction costs and intellectual property right protection exerted different effects in countries at different developing stages. The differences of developing stages referred to varying legal, infrastructure, social and political environment. To make further comparison in different groups of countries. The moderating effect of institutional factors was further evaluated through hierarchical regression models between BRICS and five OECD countries, as illustrated in Table 6. Apart from the control variables, the innovation culture exerted positive effect in OECD countries whereas the effect was insignificant in emerging countries. Moreover, the entrepreneurs' educational degree promoted organizational innovation in the "BRICS", whereas the effects
Table 6. Comparative analysis of different models between BRICS and OECD countries.

\begin{tabular}{|c|c|c|c|c|c|c|}
\hline & $\begin{array}{c}\text { Model } 1 \\
\text { BRICS } \\
\end{array}$ & $\begin{array}{c}\text { Model } 2 \\
\text { OECD }\end{array}$ & $\begin{array}{c}\text { Model } 3 \\
\text { BRICS } \\
\end{array}$ & $\begin{array}{c}\text { Model } 4 \\
\text { OECD }\end{array}$ & $\begin{array}{c}\text { Model } 5 \\
\text { BRICS } \\
\end{array}$ & $\begin{array}{c}\text { Model } 6 \\
\text { OECD }\end{array}$ \\
\hline $\mathrm{KE}$ & -1.31 & -0.13 & & & & \\
\hline $\mathrm{KE}^{\star} \mathrm{TC}$ & 0.44 & 2.18 & & & & \\
\hline $\mathrm{KE}^{\star} \mathrm{IPR}$ & 0.06 & -2.04 & & & & \\
\hline $\mathrm{AP}$ & & & $1.46^{*}$ & 1.62 & & \\
\hline $\mathrm{AP}^{\star} \mathrm{TC}$ & & & $-1.39^{* \star}$ & 1.30 & & \\
\hline $\mathrm{AP}^{\star} \mathrm{IPR}$ & & & -0.17 & -0.25 & & \\
\hline SU & & & & & $2.40^{* *}$ & 0.60 \\
\hline $\mathrm{SU}^{*} \mathrm{TC}$ & & & & & $-1.28^{\star *}$ & -0.17 \\
\hline $\mathrm{SU}^{\star} \mathrm{IPR}$ & & & & & $-1.00^{*}$ & -0.44 \\
\hline EG & $-0.36^{\star *}$ & $-0.37^{\star \star}$ & $-0.43^{\star *}$ & $-0.23^{\star}$ & $-0.17^{\star *}$ & $-0.25^{\star}$ \\
\hline Inc & $0.41^{\star \star}$ & $0.29^{*}$ & $0.36^{* *}$ & 0.20 & $0.14^{* *}$ & 0.21 \\
\hline IC & -0.16 & 0.13 & -0.13 & $0.16^{*}$ & -0.07 & 0.16 \\
\hline Sca & 0.01 & 0.02 & 0.06 & 0.02 & 0.06 & 0.02 \\
\hline Edu & $0.10^{*}$ & -0.07 & $0.09^{* *}$ & -0.06 & 0.07 & -0.04 \\
\hline
\end{tabular}

${ }^{* *} \mathrm{p}<0.01 ;{ }^{*} \mathrm{p}<0.05$.

turned neutral in developed countries. The moderating effects of institutional environment differed in different countries. Firstly, lowering transaction costs is critical in promoting the relationship between entrepreneurship and organizational innovation in emerging countries. The moderating effect appears in the dimensions of start-up entrepreneurship and adventure-taken entrepreneurship. On the contrary, the lower information-searching cost could not motivate entrepreneurs' decision on innovation. Moreover, the lower informationsearching cost would reduce enterprises' innovation when their decision-makers have better knowledge and experience. The reason of the above outcomes is mainly due to the differences of the type of innovation. According to Wang et al. (2015), explorative and exploitative innovation requires different channels of knowledge. Therefore, organizations in emerging countries rely on knowledge absorption more than knowledge creation. Consequently, the lower transaction costs would promote innovation through collaborative innovation and imitative innovation. On the other hand, enterprises in OECD countries mostly engage in high position of value chain and rely on explorative innovation more than exploitative innovation. As a consequence, the inbound innovation may overweigh the outbound innovation and imitative innovation, which validated the hypothesis 4 .

The higher protection level failed to positively moderate the relationship between entrepreneurship and organizational innovation. In emerging countries, a high degree of protection even disturbed start-up entrepreneurs' innovation decision. The outcomes overturned the hypothesis 5 . In terms of the robust check, the three dimensions of entrepreneurship were integrated into a signal variable to evaluate the effect on innovation. Moreover, the measurement of organizational innovation was changed as the participant of innovation activity (Q5EE1 in APS of GEM). The results turned out to support the hypotheses 1 and 2 . The robust check also confirmed the differences between emerging and developed countries in the moderating effect institutional environment. 


\subsection{Implications}

The first proposition of this research is that entrepreneurship can promote organizational regardless of regional environment as well as firms' characters.

In emerging countries, even though the start-up rate and self-employment rate are rising, the dynamic entrepreneurship which contribute to innovation decision is still lagging behind developed countries. According to Martinez et al. (2018) and Zhou et al. (2017), inheritance, training and incubating can promote the dynamics entrepreneurship. Therefore, the emerging countries should adapt the shortcomings of culture and education to shape the entrepreneurial companies.

Secondly, to accomplish the catch-up process and build competitive advantages, emerging countries need to embed into the global value chain and "learning by doing". On the other hand, to extend the leading time of multiple national enterprises' technology, developed countries apply TRIPs to press the developing countries to increase the degree of intellectual property right protection. In organizational level, this research proves that the higher intellectual property right protection exerts negative moderating effect on the relationship between entrepreneurship and innovation in emerging countries. According to Shapiro (2000), on the perspective of international trade, strengthening the intellectual property right in emerging countries would make the local companies lose their competitive advantages and cause "lock-in" by the rising cost of outbound innovation. Some "BRICS" countries embed the global value chain as "world factory" and seek technological upgrading through absorbing spillover from upstream of the chain. Consequently, to protect the local companies' knowledge absorption and open innovation, emerging countries should not follow the high level of intellectual property right protection in developed countries. Alone with the development of regional innovation systems and mode of multiple-participants' innovation, entrepreneurs in emerging countries should focus on inbound high-tech innovation to rise the degree of intellectual property right protection through legislation and law-enforcement.

Lastly, the transaction costs are proven to exert a significant moderating effect in emerging countries upon the relationship between entrepreneurship and organizational innovation. Due to the institutional factors, the high information-searching cost, contract cost and decision cost become main barriers of organizational innovation. The authors explained the negative effects on organizational innovation brought by high transaction costs through the spillover of regional knowledge flow and the access of collaborative innovation. To reduce the transaction costs, the government in emerging countries ought to build credit rating system and enterprises' collaboration platform to activate the effect of entrepreneurship on promoting the organizational innovation through the strength of information disclosure and interaction between different companies. Moreover, innovation culture's influence is larger in developed countries. The emerging countries should improve the infrastructure through enlarging the public expenditure. To ensure the organizational innovation of small and medium enterprises, emerging countries ought to upgrade the regional incubating environment by the mode of triple helix collaboration (government-university-industry).
Alone with the process of industry upgrading and development of dynamic entrepreneurship, the innovation culture can play a vital role in organizational innovation. To prepare for the rain, emerging countries should foster innovation culture by pushing the urbanization and household registry reform. The entrepreneurship from traditional industry clusters can diffuse to alternative industries in the process of industry transformation and upgrading in emerging countries (Giulietti et al., 2012).

\section{Conclusions}

The dynamic entrepreneurship (willingness to start-up, adventure preference, knowledge and experience) can motivate the organizational innovation. Institutional environment (transaction costs and intellectual property right protection) exert moderating effects in different countries. Additionally, this paper put forward the suggestions on how to active the organizational innovation in the background of emerging countries. Moreover, this paper offer evidence for comparative analysis of the effect of intellectual property right on the organizational innovation in different countries.

There are several limitations to be acknowledged. Firstly, the decision-makers' perception of institutional environment is not included in GEM, which may induce an error between the objective and perceived environment and the moderating effect may exist differences. Secondly, innovation culture is an acknowledged factor which affects organizational innovation, innovation culture was utilized as a control variable and measured by acceptance and public opinion on innovation. Based on the same foundation of regional culture environment, innovation culture may have collinearity with dynamic entrepreneurship.

\section{Conflict of interest}

\section{Acknowledgements}

This paper is financially supported by National Social Science Foundation of China "Explore industry cluster upgrading on the scope of global value chain: base on the background of Beijing, Tianjin and Hebei”, No. 15AGL024.

\section{References}

Acs, Z. J., \& Audrestch, D. B. (1988). Innovation in large and small firms: an empirical analysis. The American Economic Review, 78(4), 678-690.

Aparicio, S., Urbano, D., \& Audrestch, D. (2016). Institutional factors, opportunity entrepreneurship and economic growth, panel data evidence. Technical Forecasting and Social Change, (102), 45-61.

Audretsch, D. B., Kuratko, D. F., \& Link, A. N. (2016). Dynamic entrepreneurship and technology-based innovation. Journal of Evolutionary Economics, 26(3), 603-620. http://dx.doi.org/10.1007/ s00191-016-0458-4.

Bettencourt, L. M. A., Lobo, J., \& Strumsky, D. (2007). Invention in the city: increasing returns to patenting as a scaling function of metropolitan size. Research Policy, 36(1), 107-120. http://dx.doi. org/10.1016/j.respol.2006.09.026.

Boschma, R. A. (2005). Proximity and innovation: a critical assessment. Regional Studies, 39(1), 61-74. http://dx.doi.org/10.1080/0034340 052000320887. 
Cantwell, J., Dunning, J. H., \& Lundan, S. M. (2010). An evolutionary approach to understanding international business activity: the coevolution of MNEs and institutional environment. Journal of International Business Studies, 41(4), 567-586. http://dx.doi. org/10.1057/jibs.2009.95.

Carree, M., van Stel, A., Thurik, R., \& Wennekers, S. (2002). Economic development and business ownership: an analysis using data of 23 OECD countries in the period of 1976-1996. Small Business Economics, 19(3), 271-290. http://dx.doi.org/10.1023/A:1019604426387.

Coase, R. (1960). The problem of social cost. The Journal of Law \& Economics, 3, 1-44. http://dx.doi.org/10.1086/466560.

Cohen, W., Nelson, R., \& Walsh, J. (2000). Protecting their intellectual assets: appropriability conditions and why U.S. manufacturing firms patent (or not). NBER Working Paper, 7552.

Delgado, M., Porter, M. E., \& Stern, S. (2010). Clusters and entrepreneurship. Journal of Geography, 10(4), 495-518.

Ferreras-Méndez, J. L., Fernández-Mesa, A., \& Alegre, J. (2016). The relationship between knowledge search strategies and absorptive capacity: a deeper look. Technovation, 54, 48-61. http://dx.doi. org/10.1016/j.technovation.2016.03.001.

Ghazinoory, S., Narimani, M., \& Tatina, S. (2017). Neoclassical versus evolutionary economics in developing countries: convergence of policy implication. Journal of Evolutionary Economics, 27, 555-583. http://dx.doi.org/10.1007/s00191-017-0490-z.

Giulietti, C., Ning, G. \& Zimmermann, K. F. (2012). Self-employment of rural-to-urban migrants in China. International Journal of Manpower, 33(1), 96-117. http://dx.doi.org/10.1108/01437721211212547.

Godart, F. C., Maddux, W. W., Shipilov, A. V., \& Galinsky, A. D. (2015). Fashion with a foreign flair: professional experience absorb facilitate the creative innovation of organizations. Academy of Management Journal, 58(1), 195-220. http://dx.doi.org/10.5465/amj.2012.0575.

Gooris, J., \& Peeters, C. (2016). Fragmenting global business process: a protection for proprietary information. Journal of International Business Studies, 47(5), 535-562. http://dx.doi.org/10.1057/jibs.2015.44.

Gooroochurn, N., \& Hanley, A. (2007). A tale of two literature: transaction cost and property right in innovation outsourcing. Research Policy, 36(10), 1483-1495. http://dx.doi.org/10.1016/j.respol.2007.07.001.

Grigorios, L., \& Lamin, A. (2015). Knowledge, proximity and R\&D exodus. Research Policy, 45(1), 8-26.

Grossman, S. J., \& Hart, O. D. (1986). The costs and benefits of ownership: a theory of vertical and lateral integration. Journal of Political Economy, 94(4), 691-719. http://dx.doi.org/10.1086/261404.

Hart, O., \& Moore, J. (1990). Property rights and the nature of firm. Journal of Political Economy, 98(6), 1119-1158. http://dx.doi. org/10.1086/261729.

Hébert, R. F., \& Link, A. N. (2006). The entrepreneur as innovator. The Journal of Technology Transfer, 31(5), 589-597. http://dx.doi. org/10.1007/s10961-006-9060-5.

Heiman, B. A., Im, S., \& Kim, N. (2004). Beyond governance: the effects of knowledge and transaction-cost factors if innovation success. San Francisco: Strategic Problem of Formulation Empirical Paper, San Francisco State University.

Helpman, E. (1993). Innovation, institution and intellectual property rights. Econometrica, 61(6), 1247-1280. http://dx.doi.org/10.2307/2951642.

Jansen, J. J. P., Van Den Bosch, F. A. J., \& Volberda, H. W. (2005). Managing potential and realized absorptive capacity: how do organizational antecedents matter? Academy of Management Journal, 48(6), 9991015. http://dx.doi.org/10.5465/amj.2005.19573106.
Lai, E. L. C. (1998). International intellectual property rights protection and the rate of product innovation. Journal of Development Economics, 55(1), 133-153. http://dx.doi.org/10.1016/S0304-3878(97)00059-X.

Laplume, A. O., Pathak, S., \& Xavier-Oliveira, E. (2014). The politics of intellectual property rights regimes: an empirical study of new technology use in entrepreneurship. Technovation, 34(12), 807-816. http://dx.doi.org/10.1016/j.technovation.2014.07.006.

Lee, K., \& Han, T. (2016). How vulnerable is the emission market to transaction costs? An ABMS approach. Energy Policy, 90, 273-286. http://dx.doi.org/10.1016/j.enpol.2015.12.013.

Lee, S., Nam, Y., Lee, S., \& Son, H. (2016). Determinates of ICT innovations: across-country empirical study. Technological Forecasting and Social Change, 110, 71-77. http://dx.doi.org/10.1016/j.techfore.2015.11.010.

Liu, P., Li, L., \& Wang, X. (2017). Gender differences in entrepreneurship: base on the perspective of start-up motivation. Management World, $8,125-135$.

Love, J. H., \& Roper, S. (2002). Internal versus external R\&D: a study of R\&D choice with sample selection. International Journal of the Economics of Business, 9(2), 239-255. http://dx.doi.org/10.1080/13571510210134998.

Lundvall, B. A. (1993). Explaining interfirm cooperation and innovation: limits of the transaction-cost approach. In G. Grabher (Ed.), The embedded firm: on the socioeconomics of industrial network. London: Routledge.

Martin, B. R. (2016). Twenty challenges for innovation studies. Science \& Public Policy, 43(3), 432-450. http://dx.doi.org/10.1093/scipol/scv077.

Martin, S. (2002). Spillovers, appropriability and R\&D. Journal of Economics, 75, 1-32. http://dx.doi.org/10.1007/s007120200000.

Martinez, A. C., Puentes, E., \& Ruiz-Tagle, J. (2018). The effects of micro-entrepreneurship programs on labor market performance: experimental evidence from Chile. American Economic Journal: Applied Economics, 10(2), 101-124. http://dx.doi.org/10.1257/ app.20150245.

Mas-Verdú, F., Ribeiro-Soriano, D., \& Roig-Tierno, N. (2015). Firm survival: the role of incubators and business characteristics. Journal of Business Research, 68(4), 793-796. http://dx.doi.org/10.1016/j. jbusres.2014.11.030.

Misra, K., Memili, E., Welsh, D. H. B., \& Sarkar, S. (2014). The determinants of venture creation time: a cross-country perspective. The International Entrepreneurship and Management Journal, 10, 253-276. http://dx.doi.org/10.1007/s11365-012-0226-3.

Noseleit, F. (2013). Entrepreneurship, structural change and economic growth. Journal of Evolutionary Economics, 23, 735-766. http:// dx.doi.org/10.1007/s00191-012-0291-3.

Park, M. (2008). International Patent Protection. Research Policy, 27(4), 761-766.

Pellegrino, G., Piva, M., \& Vivarelli, M. (2012). Young firms and innovation: a microeconometric analysis. Structural Change and Economic Dynamics, 23(4), 329-340. http://dx.doi.org/10.1016/j. strueco.2011.10.003.

Popa, S., Soto-Acosta, P., \& Martinez-Conesa, I. (2017). Antecedents, moderators, and outcomes of innovation climate and open innovation: an empirical study in SMEs. Technological Forecasting and Social Change, 118, 134-142. http://dx.doi.org/10.1016/j.techfore.2017.02.014.

Schumpeter, J. (1928). The instability of capitalism. The Economic Journal, 38(151), 361-386. http://dx.doi.org/10.2307/2224315.

Schumpeter, J. A. (1934). The theory of economic development: an inquiry into profits, capital, credit, interest and business cycle. New Jersey: Transaction Publishers. 
Shapiro, C. (2000). Navigating the patent tickets: cross licenses, patent pools and standard setting. Innovation Policy and the Economy, 1, 119-150. http://dx.doi.org/10.1086/ipe.1.25056143.

Shinkle, G. A., \& Kriauciunas, A. P. (2012). The impact of current and founding institutions on strength of competitive aspiration of transition economies. Strategic Management Journal, 33(4), 448-458. http://dx.doi.org/10.1002/smj.1946.

Stam, E. (2015). Entrepreneurial ecosystems and regional policy: a sympathetic critique. European Planning Studies, 23(9), 1759-1769. http://dx.doi.org/10.1080/09654313.2015.1061484.

Stuetzer, M., Obschonka, M., Audretsch, D. B., Wyrwich, M., Rentfrow, P. J., Coombes, M., Shaw-Taylor, L., \& Satchell, M. (2016). Industry structure, entrepreneurship, and culture: an empirical analysis using historical coalfields. European Economic Review, 86(s1), 52-72. https://doi.org/10.1016/j.euroecorev.2015.08.012.

Stuetzer, M., Obschonka, M., Brixy, U., Sternberg, R., \& Cantner, U. (2014). Regional characteristics, opportunity perception and entrepreneurship activities. Small Business Economics, 42, 221-244. http://dx.doi.org/10.1007/s11187-013-9488-6.

Teece, D. J. (2007). Explicating dynamic capabilities: the nature and microfoundations of sustainable enterprise performance. Strategic Management Journal, 28(13), 1319-1350.

Teece, D. T., Pisano, G., \& Shuen, A. (1997). Dynamic capabilities and strategic management. Strategic Management Journal, 18(7), 509-533. http://dx.doi.org/10.1002/(SICI)1097-0266(199708)18:7<509::AIDSMJ882>3.0.CO;2-Z.
Veugelers, R. (1997). Internal R\&D expenditure and external technology sourcing. Research Policy, 26(3), 303-315. http://dx.doi.org/10.1016/ S0048-7333(97)00019-X.

Wang, H. (2011). Does the higher intellectual property right protection motivate technical innovation? Economic Research Journal, 2, 124-135.

Wang, Y., Sutherland, D., Ning, L., \& Pan, X. (2015). The evolving nature of China's regional innovation systems: insights from an explorationexploitation approach. Technological Forecasting and Social Change, 100, 140-152. http://dx.doi.org/10.1016/j.techfore.2015.07.010.

Williamson, O. (1989). Transaction cost economics. In R., Schmalensee \& R. Willig (Eds.), Handbook of industrial organization. Amsterdam: Elsevier Science Publishing.

Wong, P. K., Ho, Y. P., \& Autio, E. (2005). Entrepreneurship, innovation and economic growth: evidence from GEM data. Small Business Economics, 24, 335-350. http://dx.doi.org/10.1007/s11187-005-2000-1.

Wu, C., \& Tang, D. (2016). Degree of intellectual property right protection, technical innovation and enterprise performance: base on the evidence of China's listed companies. Economic Research Journal, 11, 125-139.

Zhan, Y. (2013). Empirical study of China's intellectual property right protection: international comparison and critical evaluation. Science in Science of Science, 9, 1347-1354.

Zhao, F. (2005). Exploring the synergy between entrepreneurship and innovation. International Journal of Entrepreneurial Behaviour \& Research, 11(1), 25-41. http://dx.doi.org/10.1108/13552550510580825.

Zhou, H., Jean-Louis, A., \& Tao, R. (2017). Entrepreneurship's intergenerational transmission and start-up of rural migration population in urban. Economic Research Journal, 11, 74-87. 